\title{
Upscaling and Evaluation of BARI Inclined Plate Planter
}

\author{
M. A. Hoque ${ }^{1}$ and M. R. Karim ${ }^{2}$ \\ ${ }^{1}$ FMP Engineering Division, Bangladesh Agricultural Research Institute, Gazipur-1701, Bangladesh; \\ ${ }^{2}$ OFRD, Bangladesh Agricultural Research Institute, Pabna, Bangladesh
}

*Corresponding author and Email: arshadul@bari.gov.bd

Received: 8 February 2015

Accepted: 12 December 2015

\begin{abstract}
The BARI inclined plate planter was developed for one pass tillage and seeding operation. But the planter was not capable of planting small seeds as seeds were entering between the plate and base. So, six additional MS base plates were incorporated in the planter. Three plates were redesigned and fabricated for maize seed ( 9 cells); for wheat, mungbean, lentil, jute, etc (32 cells) and for rice seed (11 cells). Changing of inclination of the plate is needed to use same (32 seed cell) plates for different crops and to calibrate the planter for $10 \%$ more or less seed than the predefined rates. Field test of BARI developed inclined plate planter was conducted in Gazipur, Pabna, and Barisal and its performance were evaluated. The planter was tested for sowing maize, wheat and mungbean during 2011-12. Effective field capacity and field efficiency were $0.17 \mathrm{ha} / \mathrm{h}$ and $75 \%$, respectively. Coefficient of seed distribution uniformity and coefficient of planting depth uniformity were 97 and $94 \%$, respectively. Time and cost saving to complete land preparation and planting of maize by inclined plate planter were 90 and $86 \%$, respectively than conventional hand planting. The payback period of the BARI planter is 1.20 year. Break-even use time is 97 hours.
\end{abstract}

Keywords: Seed metering device, Field efficiency, Field capacity, Payback period

\section{Introduction}

Traditional tillage method requires more time for land preparation which causes moisture loss or clod formation. Every crop has its optimum time of sowing/planting. Delay sowing/planting reduces yield significantly (Jat, 2013). The lack of agricultural labor lead to increase in production cost, therefore mechanization represents an important factor to reduce the costs and increase the productivity (Hobbs, 2003). Land preparation is one of the major activities to establish crop. Additional economic benefit incurred through higher yield in reduced tillage (Hobbs, 2003). Upland crops like maize, wheat, paddy, jute, pulses and oil seeds can be cultivated under minimum tillage. Bangladeshi farmers still practicing hand broadcasting of seed in conventionally tilled soil.

Planter type and cropping pattern also had significant effects on germination at $1 \%$ probability level and pneumatic ridge planter had maximum percentage of seed germination (87.32\%) (Jabraeil and Farjam, 2013). Power tiller operated seeder (PTOS) performs tillage operation, seeding in line and seed covering simultaneously which is named as minimum tillage (Hossain et al., 2014). Strip till planting is a system in which tilling the planting strips and 
placed seeds and fertilizers simultaneously in a single operation, thereby reducing the number of field operations which is environment friendly because of low fuel consumption and less soil erosion (Dabney et al., 2004). Bed planting is a system where land is prepared conventionally and raised bed is prepared using bed planting machine. Crops are planted in row on the top of the bed and irrigation water is applied in the furrows between the beds (Islam, 2012; Islam et al., 2013).

Various researcher have evaluated many types of seed drill but most of them are four wheel tractor operated (Ghosal and Pradhan, 2013; Reddy et al., 2012; Altikat and Celik, 2012; Afzalinia et al., 2006). Power tiller operated inclined plate type planter (BARI seeder Model-1) was developed by FMP Engineering Division of BARI (Ahmed et al., 2005; Matin et al., 2008). The planter was tested and evaluated for planting different crops like maize, wheat, pulses and oilseeds in field condition. The field performances results were satisfactory. But the planter required tilled land before use which is costly and time consuming. Then a planter (BARI seeder Model-2) was developed by placing inclined plate metering device on BARI high speed rotary tiller for one pass tillage and seeding operation (Wohab et al., 2011). Fluted roller meter is ideal for continuous mass seeding but inclined plate meter is excellent in spaced seeding (Baker et al., 2007). Inclined plate is due to the increased precision with which farmers can plant larger seeds like maize, while facilitating good establishment for medium-sized seeds like wheat or rice (Krupnik et al., 2013). Inclined plates pick up seeds from the seed box, carry them forward and drop them in precise quantities through a tube and furrow opener into the soil. The plates are designed to carry seed of a particular shape and size, the seed used when drilling should be carefully selected for optimal performance (Murray et al., 2006). The Model-1 was toolbar mounted seeder and there was no option for transferring rotary motion to the seeder but the model-2 required option for rotary energy for soil tillage. In both models, separate seed plates were used for individual crops which is costly. Also there was no scope to calibrate the seeder for $10 \%$ more or less seed than the predefined rate in the Model-2. During the use of inclined plate planter in farmer's field, the planter was not capable of planting small seeds. For the continuing improvement and evaluation of the planter for various crops in different locations, the experiment was conducted with the following objectives; i) to improve the planter for easy operation and ii) to study the field performances of BARI inclined plate planter in farmers' field.

\section{Materials and Methods}

\subsection{Modification}

Though the initial test prototype was made carefully in FMP Engineering laboratory when the planter was produced largely, it was difficult to control uneven bending due to arc welding. Due to uneven base of the plates, small seeds were entering between the plate and base. So, six additional MS base plates were incorporated in the planter to produce uniform flat surface so that seed could not enter between base and plate. The diameter of the base plate was $127 \mathrm{~mm}$ with internal groove of $117 \mathrm{~mm}$ diameter. A bush was inbuilt in the base plate with length, internal diameter and outer diameter of 30,25 and 15 $\mathrm{mm}$, respectively. It was found during the test that for sowing of wheat $(120 \mathrm{~kg} / \mathrm{ha})$ the $\mathrm{rpm}$ of the plates have to increase. Based on this, the plates were tested and an additional pinion of 14 teeth was added by the side of the power taking pinion of 19 teeth. Three plates were redesigned and fabricated with aluminum. Opening of the seed cell was redesigned with higher right angle to make the groove steep enough to decrease the time delay for seed dispersing as much as possible between the seeds consecutively dropped from the groove. Thus the opening of the seed cell was more in the contact surface than the appearing surface of the plate. Thickness and diameter of plates were 5.5 and $115 \mathrm{~mm}$, respectively. The numbers of seed cell at the periphery of the plate were 9 for large seed (maize), 32 for small seed (wheat, mungbean, 
lentil, jute, etc) and 11 for rice seed. Changing of inclination of the plate is needed to use same ( 32 seed cell) plates for different crops and to calibrate the planter for $10 \%$ more or less seed than the predefined rate. Hence provision of changing inclination was incorporated that was absent in the previous version. A photographic view of the improved planter is shown in Figure 1. Before field testing, the planter was tested in laboratory with different seeds.

\subsection{Laboratory test}

After fabrication of the planter, it was tested in the divisional workshop for maize, wheat, mungbean, lentil and rice seed during 2011-12. Calibration was done with the modified planter and plates. To calibrate the machine the numbers of furrow opener was adjusted according to crop (example: 6 lines for wheat, rice, jute; 4 lines for lentil, mungbean and mustard; and 2 lines for maize). The planter was operated in $20 \mathrm{~m}$ long field after setting polybags with rubber band in the furrow opener. The following equation was used to calibrate the machine and check the capability of the planter to dispense required amount of seed through each furrow opener after operating in a field for a specific distance.

Seed in Polibag $(\mathrm{kg})=$

$\underline{\text { Seed rate }(\mathrm{kg} / \mathrm{ha}) \times \text { Line to line distance }(\mathrm{m}) \times \text { Travel distance }(\mathrm{m})}$ 10,000

To calculate the field efficiency of the planter, a field of $20 \times 10 \mathrm{~m}$ was planted. The planting operation was performed longitudinally with a forward speed of $1.3 \mathrm{~km} / \mathrm{h}$. While planting this area, the effective operating times and the times spent to fill the seed hopper were recorded and using Equation 1 (Kepner, 1978) the field efficiency was calculated for the inclined plate planter.

$$
e=100 \frac{T_{e}}{T_{t}}
$$

Where,

$T e=$ effective operating time (min),

$T_{t}=$ total time $(\mathrm{min})$, and

$e=$ field efficiency $(\%)$.

Effective field capacity was also calculated using Equation 2 (Kepner, 1978).

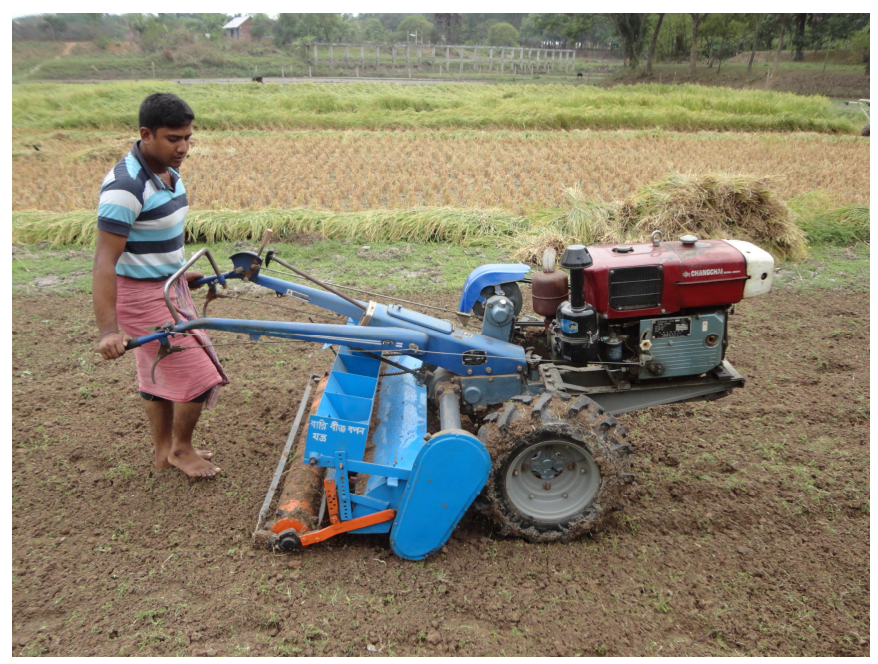

Figure 1. Photographic view of the improved planter 


$$
C_{e}=\frac{W S e}{1000}
$$

Where,

$C e=$ effective field capacity $(\mathrm{ha} / \mathrm{h})$,

$W=$ implement effective width (m), and

$S=$ forward speed $(\mathrm{km} / \mathrm{h})$.

To calculate the coefficient of uniformity of seed distribution, prepared land strip with measurements of $20 \times 1.3 \mathrm{~m}$ was filled with a layer of fine soil of 50-mm thickness. Planting was performed on the strip at a speed of 1.3 $\mathrm{km} / \mathrm{h}$. An area of two rows with a length of one meter was randomly selected using a wooden frame in each replication. The planted seeds in this area were separated from the soil using a sieve. The coefficient of uniformity of seed distribution was computed using Equation 3 (Senapati et al., 1992).

$$
S_{e}=100\left(1-\frac{Y}{D}\right)
$$

Where,

$\mathrm{Se}=$ coefficient of seed distribution uniformity $(\%)$,

$Y=$ average numerical deviation of number of plants per meter length of row from average number of plants per meter run, and

$D=$ average number of plants per meter length of row.

To measure plant depth uniformity, planted seeds were irrigated gently and adequate time was provided for seedling emergence. Once emerged, seedlings were cut at the soil surface. A part of the stem that was inside the soil (from soil surface to seed remnants on the root) was taken out and its length was measured. This length was considered as a criterion to compare the seeding depth of the planter. 20 samples were taken, and the coefficient of planting depth uniformity was calculated using Equation 4 (Senapati et al., 1992).

$$
S_{d}=100\left(1-\frac{Y_{d}}{D_{d}}\right)
$$

Where,

$\mathrm{S}_{\mathrm{d}}=$ coefficient of planting depth uniformity $(\%)$,
$\mathrm{Y}_{\mathrm{d}}=$ average numerical deviation of depth of seeds planted from pre-set planting depth and $\mathrm{D}_{\mathrm{d}}=$ average depth of seeds planted.

\subsection{Field performance test}

Field performance test of the planter was conducted in divisional experimental plot of BARI, Gazipur, farmers' field of Pabna and Barisal during 2011-12. In Gazipur, Inclined plate planter was tested for maize (BARI hybrid maize-7) in clay loam soil at $23 \%$ moisture content. The experiment was conducted with four treatments: $\mathrm{T}_{1}=$ Bed planting with inclined plate, $\mathrm{T}_{2}=$ Inclined plate planter with full tillage, $\mathrm{T}_{3}=$ Inclined plate plates with strip tillage and $\mathrm{T}_{4}=$ Conventional hand planting. All the treatments were replicated thrice with RCB design. Date of sowing was 24 January 2012 and the harvesting date was 17 June 2012. Spacing of maize seed was $60 \times 20 \mathrm{~cm}$. In Pabna, wheat (Bijoy) was sown in farmer's field with inclined plate planter on 2 December 2012 and harvested on 12 April 2012. In Barisal, the inclined plate planter was used in the farmer's field for sowing maize (BARI maize 9), wheat (BARI Gom 26) and mungbean (BARI mung 6). Irrigation, fertilizing, weeding and other intercultural operations were done timely. Data of yield and yield contributing character of maize for different tillage and sowing methods were collected from Gazipur. Collected data were analyzed with MSTAT statistical tool.

\section{Results and Discussion}

The modified planter was tested in FMP Engineering divisional laboratory and field. The planter can be used for different crops using selected plates and pinion. Selection of plate and pinion for different crops and calibration results are shown in Table 1. Advantage of the inclined plate planter is that farmers need not to calibrate the machine rather he can easily go to the field, select plates suitable for the crops, select pinion for chain adjustment and check the inclination of the plates. However, user of the planter can check the machine by operating in $20 \mathrm{~m}$ long field and can check the observed amount with the values in the Table 1 . 
Table 1. Selection of plate and pinion for different crops and calibration results

\begin{tabular}{lccll}
\hline \multicolumn{1}{c}{ Seed } & $\begin{array}{c}\text { Plate } \\
\text { (seed cell })\end{array}$ & $\begin{array}{c}\text { Pinion } \\
\text { (teeth) }\end{array}$ & \multicolumn{1}{c}{ Remarks } & $\begin{array}{l}\text { Observed amount of } \\
\text { seed in the polybags }\end{array}$ \\
\hline Maize & 9 & 14 & For 20 cm seed to seed spacing & $100 \mathrm{nos}$ \\
Maize & 9 & 19 & For 25 cm seed to seed spacing & $80 \mathrm{nos}$ \\
Wheat & 32 & 14 & Normal inclination & $48 \mathrm{gm}$ \\
Mungbean & 32 & 19 & Slightly vertical position of the plate & $27 \mathrm{gms}$ \\
Lentil & 32 & 19 & More vertical position of the plate & $21 \mathrm{gms}$ \\
Jute & 32 & 19 & Mixing rice bran with 1:3 to 1:4 & 4 gms \\
Rice & 12 & 14 & For 15 cm hill to hill spacing & 20 to 25 gms \\
Rice & 12 & 19 & For 20 cm hill to hill spacing & 12.5 to 15gms \\
\hline
\end{tabular}

Table 2. Performance of inclined plate for seed placing (maize)

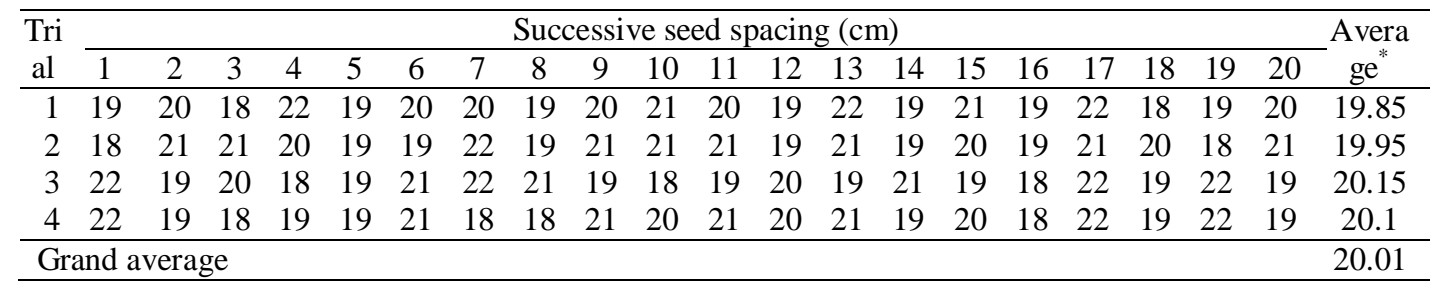

*Figures within the bracket indicate standard deviation

Table 3. Performance parameters of inclined plate planter

\begin{tabular}{ll}
\hline Parameter & Value \\
\hline Field efficiency, $\%$ & 75 \\
Forward speed, $\mathrm{km} / \mathrm{h}$ & 1.3 \\
Field capacity, ha/h & 0.17 \\
Depth of tillage, $\mathrm{cm}$ & $6-8$ \\
Average depth of placing maize seed, cm & 3.75 \\
Coefficient of seed distribution uniformity, $\%$ & 97 \\
Coefficient of planting depth uniformity, $\%$ & 94 \\
Time saving by the planter over traditional $(\%)$ & 90 \\
\hline
\end{tabular}

Table 4. Effect of planting method on the yield of maize

\begin{tabular}{cccccccccc}
\hline $\begin{array}{c}\text { Treat } \\
\text { ment }\end{array}$ & $\begin{array}{c}\text { Plant } \\
\text { Populatio } \\
\text { n/ m }\end{array}$ & $\begin{array}{c}\text { Plant } \\
\text { height } \\
(\mathrm{cm})\end{array}$ & $\begin{array}{c}\text { No. of } \\
\text { Cob/ } \\
\text { plot }\end{array}$ & $\begin{array}{c}\text { Cob } \\
\text { length } \\
(\mathrm{cm})\end{array}$ & $\begin{array}{c}\text { Cob } \\
\text { dia. } \\
(\mathrm{cm})\end{array}$ & $\begin{array}{c}\text { No. of } \\
\text { filled } \\
\text { grain/cob }\end{array}$ & $\begin{array}{c}\text { No. of un- } \\
\text { filled } \\
\text { grain/cob }\end{array}$ & $\begin{array}{c}1000 \\
\text { grain } \\
\text { weight }(\mathrm{g})\end{array}$ & $\begin{array}{c}\text { Yield } \\
(\mathrm{t} / \mathrm{ha})\end{array}$ \\
\hline $\mathrm{T}_{1}$ & 7.43 & 217.57 & 212.33 & 18.40 & 15.29 & 582.3 & $9.43 \mathrm{c}$ & 295.29 & 5.13 \\
$\mathrm{~T}_{2}$ & 7.71 & 249.03 & 231.67 & 17.18 & 14.63 & 544.4 & $17.03 \mathrm{a}$ & 308.48 & 5.81 \\
$\mathrm{~T}_{3}$ & 7.72 & 229.2 & 234.33 & 17.93 & 15.2 & 562.93 & $13.93 \mathrm{ab}$ & 306.92 & 6.13 \\
$\mathrm{~T}_{4}$ & 8.27 & 228.33 & 275.33 & 17.92 & 15.23 & 546.53 & $10.47 \mathrm{bc}$ & 294.75 & 6.05 \\
\hline
\end{tabular}


Performance of inclined plate for seed placing (maize) is shown in Table 2. Average spacing of the maize seed was found to be $20.01 \mathrm{~cm}$. Maximum and minimum seed to seed distances were $22 \mathrm{~cm}$ and $18 \mathrm{~cm}$, respectively. This variation might be for lateral movement of the seeds on soil surface.

Performance parameters of inclined plate planter are given in Table 3. It was found that the field efficiency of the planter was $75 \%$ and the field capacity of that was $0.17 \mathrm{ha} / \mathrm{h}$. During the test, forward speed was $1.3 \mathrm{~km} / \mathrm{h}$. If the operator is trained then the forward speed will be more which will ensure more field capacity of the planter. The inclined plate planter can maintain 6-8 cm depth of tillage. For successful germination of maize expected seed depth was 4 $\mathrm{cm}$ but the average depth of placing maize seed was found to be $3.75 \mathrm{~cm}$. Coefficient of seed distribution uniformity and coefficient of planting depth uniformity were $97 \%$ and $94 \%$, respectively.

Effect of planting method on the yield of maize is shown in Table 4 . There was no significant effect of planting methods on yield and yield contributing characters of maize except number of unfilled grain per cob. Significantly lowest number of unfilled grain per cob was found in bed plating with highest number of filled grain but it could not contribute in higher yield due to lowest plant population. Highest number of unfilled grain was found in full tillage that was statistically identical for strip tillage. However, the inclined plate planter ensured good plant population and yield as well both in full tillage and strip tillage. It was first year trial and the land was newly improved. Time saving to complete land preparation and planting of maize by inclined plate planter were found to be $90 \%$ than conventional hand planting.

Yield and yield contributing character of wheat sown at Pabna is given in Table 5. Farmers felt comfort to get line sown field by using inclined plate planter. The planter ensured good germination and number of tiller of wheat in line.

Yield and yield contributing character of mungbean, wheat and maize sown at Barisal is shown in Table 6. Yield of BARI Mungbean-6, BARI Gom 26 and BARI Hybrid Maize-9 were $0.98,4.59$ and 8.05 ton/ha in the farmer's field of Barisal. Farmers were happy and gave positive response about the inclined plate planter.

Table 5. Yield and yield contributing character of wheat grown at Pabna

\begin{tabular}{ccccccc}
\hline Crop & $\begin{array}{c}\text { Plant Population } \\
\left(\mathrm{No} / \mathrm{m}^{2}\right.\end{array}$ & $\begin{array}{c}\text { Plant height } \\
(\mathrm{cm})\end{array}$ & $\begin{array}{c}\text { Length of } \\
\text { panicle }(\mathrm{cm})\end{array}$ & $\begin{array}{c}\text { Number of } \\
\text { grains/panicle }\end{array}$ & $\begin{array}{c}1000 \\
\text { grain wt. g }\end{array}$ & $\begin{array}{c}\text { Yield } \\
(\mathrm{t} / \mathrm{ha})\end{array}$ \\
\hline Bijoy & 213 & 85.26 & 10.33 & 32.54 & 42.5 & 4.1 \\
\hline
\end{tabular}

Table 6. Yield and yield contributing character of mungbean, wheat and maize grown at Barisal

\begin{tabular}{lccccccc}
\hline \multicolumn{1}{c}{ Crop } & $\begin{array}{c}\text { Plant } \\
\text { population } \\
/ \mathrm{m}^{2}\end{array}$ & $\begin{array}{c}\text { Plant } \\
\text { height } \\
\mathrm{cm}\end{array}$ & $\begin{array}{c}\text { Num. } \\
\text { of pod / } \\
\text { plant }\end{array}$ & $\begin{array}{c}\text { Seed/pod } \\
\text { or grain/ } \\
\text { panicle }\end{array}$ & $\begin{array}{c}\text { Length of } \\
\text { pod or } \\
\text { cob cm }\end{array}$ & $\begin{array}{c}1000 \\
\text { grain } \\
\text { wt. g }\end{array}$ & $\begin{array}{c}\text { Yield } \\
(\mathrm{t} / \mathrm{ha})\end{array}$ \\
\hline BARI Mungbean-6 & 21 & 35.92 & 16.22 & 9.08 & 6.38 & 27.73 & 0.98 \\
BARIGom 26 & 219.3 & 93.40 & - & 41.0 & - & 44.0 & 4.59 \\
BARI Hybrid & 8 & 215.30 & - & 765 & 105 & 345 & 8.05 \\
Maize-9 & & & & & & &
\end{tabular}


Table 7. Cost parameters for land preparation and planting for maize production

\begin{tabular}{|c|c|c|c|}
\hline$\overline{\text { Sl. No }}$ & Parameters & Seeder & Manual \\
\hline 1 & Price of the planter,TK & 160000 & \\
\hline 2 & Life of the planter, yr & 8 & \\
\hline 3 & Annual use, $\mathrm{h}$ & 340 & \\
\hline \multirow[t]{6}{*}{4} & Annual fixed cost, $\mathrm{Tk} / \mathrm{yr}$ & & \\
\hline & a) Depreciation & 18000 & \\
\hline & b) Interest (12.5\%) & 10560 & \\
\hline & c) Repair, maintenance and shelter & 5600 & \\
\hline & Total fixed cost, Tk/yr & 34160 & \\
\hline & Total fixed cost, $\mathrm{Tk} / \mathrm{h}$ & 100.47 & \\
\hline \multirow[t]{6}{*}{5} & Variable cost & & \\
\hline & a) Diesel, Tk/h & 110 & \\
\hline & b) Operator (labour@ Tk 300/day), Tk/h & 37.50 & \\
\hline & c) Land preparation, $\mathrm{Tk} / \mathrm{ha}$ & & 5400 \\
\hline & d) Labour for line sowing, Tk/ha & & 4800 \\
\hline & Total variable cost, $\mathrm{Tk} / \mathrm{h}$ & 147.50 & \\
\hline 6 & Grand total $(\mathrm{FC}+\mathrm{VC}), \mathrm{Tk} / \mathrm{h}$ & 247.97 & \\
\hline 7 & Cost for land preparation and planting, Tk/ha & 1459 & 10200 \\
\hline 8. & Income (Considering custom hireing ), Tk/ ha & 3750 & \\
\hline 9. & Net return, $\mathrm{Tk} / \mathrm{yr}$ & 132420 & \\
\hline 10. & Pay back period, yr & 1.2 & \\
\hline 11. & Break-even time, $\mathrm{h}$ & 97 & \\
\hline
\end{tabular}

Cost parameters for land preparation and planting for maize production are shown in Table 7. It was observed that the cost for land preparation and planting for inclined plate seeder was $86 \%$ less than the conventional maize planting method. If the planter used for custom hiring, net return was found to be Tk 132420 per year. The payback period of the BARI planter is 1.20 year. Break-even use time is 97 hours.

\section{Conclusions}

The planter was improved with addition of six MS base plates and an additional pinion of 14 teeth was added by the side of the power taking pinion of 19 teeth. Three plates were redesigned and fabricated. Provision of changing inclination was incorporated. Field efficiency of the planter was $75 \%$ and the field capacity of that was 0.17 $\mathrm{ha} / \mathrm{h}$. Coefficient of seed distribution uniformity and coefficient of planting depth uniformity were 97 and 94\%, respectively. Time and cost saving to complete land preparation and planting of maize by inclined plate planter were 90 and $86 \%$, respectively than conventional hand planting. The payback period of the BARI planter is 1.20 year. Break-even use time is 97 hours.

\section{References}

Afzalinia, S., Shaker, M. and Zare, E. 2006. Performance evaluation of common grain drills in Iran. Canadian Biosystems Engineering, 48(2): 39-43.

Ahmed. S., Matin, M. A., Roy, K, C., Amin, M. N. and Islam, M. S. 2005. Field performance test of power tiller operated planter for maize, wheat and pulses crop, Annual research report, BARI.

Altikat, S. and Celik, A. 2012. Effects of different no-till seeders and factor forward speeds on the soil physical properties and seed emergence of summer vetch and 
winter wheat. Journal of Agricultural Sciences, 18:21-30.

Baker, C. J., Saxton, K. E., Ritchie, W. R., Chamen, W. C. T., Reicosky, D. C., Ribeiro, M. F. S., Justice, S. E. and Hobbs, P. R. 2007. No-tillage seeding in conservation agriculture. Second Edition. Food and Agriculture Organization of the United Nations. Nosworthy Way, Wallingford, Oxfordshire, OX10 8DE, UK. 326 p.

Dabney, S. M., Wilson, G. V., McGregor, K. C. and Foster, G. R. 2004. History, residue, and tillage effects on erosion of locssial soils. Trans. ASAE, 47:767-775.

Ghosal, M. K. and Pradhan, S. C. 2013. Performance study of a low cost manually operated cup feed metering seed drill for sowing green gram. Agricultural Engineering Today, 37(1): 37-41.

Hobbs, R. P. 2003. Reduced and zero-tillage options. In: Addressing Resource Conservation Issues in Rice-Wheat Systems of Sough Asia: A Resource Book. Rice-Wheat Consortium for the Indo-Gangetic Plains - International Maize and Wheat Improvement centre, New Delhi. 109-112 pp.

Hossain, M. I., Gathala, M. K., Tiwari, T. P. and Hossain, M. S. 2014. Strip tillage seeding technique: A better option for utilizing residual soil moisture in rainfed moisture stress environments of North-West Bangladesh. International Journal of Recent Development in Engineering and Technology, 2(4):132-136.

Islam, A. K. M. S., Hossain, M. M. and Saleque, M. A. 2013. Evaluation of direct seeded rice planter under minimum tillage practices. The Agriculturists, 11(2):87-95.

Islam, A.K.M.S. 2012. Development of multicrop planter for conservation agriculture. PhD Thesis. Department of farm power and machinery. Bangladesh Agricultural University. Mymensingh.

Jabraeil, T. and Farjam, A. O. 2013. Comparison of performance planting methods on ridge and conventional soybean cultivated under dry and wet seedbed condition in North-West Iran. American-Eurasian Journal of Agriculture \& Environmental Sciences, 13 (1): 109-114.

Jat, L. K., Singh, S. K., Latare, A. M., Singh, R. S. and Patel, C. B. 2013. Effect of dates of sowing and fertilizer on growth and yield of wheat (Triticum aestivum) in an Inceptisol of Varanasi. Indian Journal of Agronomy, 58(4): 168-171.

Kepner, R. A., Bainer, R. and Barger, E. L. 1978. Principles of Farm Machinery, 3rd edition. Westport, CT: AVI Publishing Company Inc, 25-218 pp.

Krupnik, T. J., Santos Valle, S., McDonald, A. J., Justice, S., Hossain, I. and Gathala, M. K. 2013. Made in Bangladesh: Scaleappropriate machinery for agricultural resource conservation. Mexico, D.F.: CIMMYT, $100 \mathrm{p}$.

Matin, M. A., Islam, M. S. and Amin, M. 2008. Demonstration of BARI power tiller operated planter for Soybean and Maize, Annual research report, BARI.

Murray, J. R., Tullberg, J. N., Basnet, B. B. 2006. Planters and their components: types, attributes, functional requirements, classification and description. The University of Queensland and Australian Centre for International Agricultural Research Monograph No. 121. Canberra, Australia, 118-141 pp.

Reddy, B. S., Satyanarayana, Adake, R. V. and Anantachar, M. 2012. Performance of seed planter metering mechanisms under simulated conditions. Indian Journal of Dry land Agricultural Research \& Development, 27(2): 36-42.

Senapati, P. C., Mohapatra, P. K. and Dikshit, U. N. 1992. Field evaluation of seeding devices for finger-millet. Agricultural Mechanization in Asia, Africa, and Latin America, 23(3): 21-24.

Wohab, M. A., Hoque, M. A and Hassan, M. S. 2011. Development of inclined plate planter for conservation tillage. Journal of Agricultural Engineering. The Institute of Engineers, Bangladesh, 39/AE (1): 33-39. 